\title{
The Construction of the Indonesian Government's Repressive Counter-Terrorism Policy
}

\author{
Ardli Johan Kusuma1*), Tulus Warsito' ${ }^{1}$, Surwandono' ${ }^{1}$, Ali Muhammad1, \\ Mega Hidayati', Muhlis Madani² \\ ${ }^{1}$ Doctoral Program of Political Islam - Political Science, Universitas Muhammadiyah Yogyakarta, \\ Jl. Brawijaya, Bantul, Yogyakarta 55183, Indonesia. \\ ${ }^{2}$ Department of Public Administration, Faculty of Social and Political Sciences, \\ Universitas Muhammadiyah Makassar, Jl. Sultan Alauddin No.259, Makassar 90221, Indonesia.
}

Received: 12 March 2019; Revised: 23 July 2019; Accepted: 31 July 2019

\begin{abstract}
The Indonesian government has made a counter-terrorism legal instrument starting in 2001. And the making of counter-terrorism policies in Indonesia was carried out after the 9/11 event. Even though the phenomenon of terrorism that occurred in Indonesia existed before 2001. Even since Indonesia became an independent state, there have been many events that can be classified into the phenomenon of terrorism. But the Indonesian government responded by making legal instruments after 2001. In overcoming terrorism, the Indonesian government prefers a repressive approach. Detachment 88 as a special anti-terrorist force, allegedly has committed many human rights violations. Even in the last 10 years, at least 120 suspected terrorists were killed in the arrest process and 40 people were victims of wrongful arrests. In addition, more than $80 \%$ of them were subjected to torture. However, the repressive approach has not been able to reduce the number of terrorist attacks in Indonesia. Therefore, this research seeks to find what factors that influencing the Indonesian government to make repressive counter-terrorism policies in Indonesia. The findings revealed the existence of several factors including the persuasion of the international community, the influence of international norms, and the perception of the Indonesian government in understanding the threat of terrorism which is influenced by past experience.
\end{abstract}

Keywords: Counter-Terrorism Policy; Persuasion; International Norms; State Perception; State experience

How to Cite: Kusuma, A. J., Warsito, T., Surwandono, S., Muhammad, A., Hidayati, M., \& Madani, M. (2019). The Construction of the Indonesian Government's Repressive Counter -Terrorism Policy. Otoritas : Jurnal Ilmu Pemerintahan, 9(2), 107-125.

Permalink/DOI: https://doi.org/10.26618/ojip.v9i2.1845

${ }^{*}$ Corresponding Author.

E-Mail : ardli.johan@yahoo.com

Copyright (C) 2019, Otoritas : Jurnal Ilmu Pemerintahan, ISSN: 2088-3706 (Print), ISSN: 2502-9320 (Online) 


\section{INTRODUCTION}

Terrorism has become one of the popular issues in the international community. This issue is considered a serious threat to countries in the world. The threat of terrorism is inseparable from the social construction of the international community. Many countries in the world have put the terrorist label on certain groups, which makes them appear as threats against humanity (Hülsse \& Spencer, 2008). The phenomenon of terrorism is not entirely new. However, the study of terrorism only became popular after the 2000s. Some of the triggers were the terrorist attacks on the World Trade Center and Pentagon building in 2001.

Many countries have developed various policies against terrorism. For reasons of national security, they chose a repressive approach with hard power instruments to address terrorism (Tams, 2009). This approach was initiated by several influential countries, such as the US against Al-Qaeda and Israel against the Islamic extremists that were considered a threat to the country (Jamwal, 2003).

After the 9/11 incident, the Indonesian government created a set legal instrument about terrorism, which tended to violate the freedom of civil society (Surwandono, S., Retnoningsih, T. A. S., Alkatiri, 2018). Though the phenomenon of terrorism in Indonesia has existed since Indonesia became an independent state, although some of these phenomena at that time were interpreted as rebellion, after $9 / 11$ the Indonesian government had a new perception regarding crime groups which were later interpreted as terrorist groups.

After the 9/11 incident, the government also created a special force named Special Detachment 88 under the auspices of the Indonesian National Police. In some cases, Special Detachment 88 performed a violation of human rights when carrying out their duties and func- tions (Kusuma, 2018). In the last 10 years, at least 120 terrorist suspects were killed during arrest and 40 people were victims of wrongful arrest. In addition, more than $80 \%$ of the suspects were tortured during arrest (Almas, 2016). In fact, the police use violence during arrest and investigation. There has been no clear resolution for the 120 people killed during the arrest. This means that the victims who died have not received justice (Sani, 2018). An example is the case of Siyono's death in 2016. Siyono was arrested by the Densus 88 for allegedly involved in terrorist networks. In the process of detention, Siyono died and is thought to have experienced violence. The National Commission on Human Rights and the Parliament of the Republic of Indonesia have found the facts of human rights violations in the case (Komisi III DPR RI, 2016).

Another example is the acts of violence committed by Detachment 88 in the arrest of terrorist suspects on January 22, 2007, in Poso. Detachment 88 is alleged to have used acts of violence to cause death. The event was recorded in a video and became popular on YouTube media (Tempo.co, 2013).

In February 2013, the National Human Rights Commission received a report regarding the video. Then on March 11, 2013, they began an investigation regarding the truth of the video.

After conducting an investigation, the National Human Rights Commission found several facts, including there, were 13 people killed in the arrest process (victims were civilians and not suspected terrorists); the victim was actually still alive and made it possible to be saved, but unfortunately there were no efforts to help, even seemingly deliberately left until finally killed.

The National Human Rights Commission condemned these inhumane cruel acts carried out by the police (Detachment 88). Moreover, the fact is that most of the dead in the condition of 
the corpse was very horrible (Komnas HAM, 2013).

In 2013, the Indonesian National Human Rights Commission also stated that Detachment 88 often commits human rights violations in carrying out its duties and functions, including: deprivation of one's freedom, deprivation of human lives, seizure of property objects, torture, cruel treatment, creation of fear and threats, efforts to inhibit communication, violations of the use of legal counsel and violations of the right to worship. The National Human Rights Commission then concluded that there were systemic and widespread violations, mainly in 4 matters, namely, attempted murder, property seizure, torture and serious legal violations against suspected terrorist networks (Fajar, 2013)

The Indonesian National Police has used the anti-terrorism law as the main reason for carrying out repressive operations to deal with terrorist suspects. However, the repressive approach has not been able to reduce the number of terror attacks. It was shown by the terrorist attacks from 2002 to 2016, in 2011 and beyond, the number of terror attacks tended to increase compared to the previous year (Ritchie et al. 2018).

Previous researchers have conducted research on the theme of counterterrorism policies. Various findings and conclusions have been presented in scientific works written by previous researchers. For example Christian J. Tams (Tams, 2009), Endi Haryono (Haryono, 2010), Hery Firmansyah (Firmansyah, 2010), and Erwin Yusup Sitorus (Sitorus, 2016), who have used the realism paradigm in looking at national security policies in order to fight terrorism taken by the state, which only relies on national security factors that are materialism, so that it seems Repressive policies taken are rational choices. Then there is Ali Muhammad who also uses the realism paradigm which argues that Indonesian counter-terrorism policies have been influenced by the interests of the other countries, in this case, the US and Australia have an interest in the war on terror. This influence was formed through assistance or pressure on the Indonesian government (Muhammad, 2015). The realism paradigm is not able to see the factors that influence the security policy of an immaterial nature. So that the paradigm of realism cannot see the phenomenon of counter-terrorism policy in Indonesia in a comprehensive manner, which is actually more influenced by social construction (international norms).

For this reason, the paradigm that can explain the phenomenon of Indonesia's national security policy in the context of tackling terrorism using a repressive approach can only be explained properly using a constructivism approach. Constructivism approach has also been used by several researchers to conduct a study of cases of state policies in tackling terrorism, as was done by previous researchers: Daniel Benjamin (Benjamin, 2008), Ahmad Zahid Hamidi (Hamidi, 2016), N.S. Jamwal (Jamwal, 2003), Sidratahta Mukhtar (Mukhtar, 2016). But the researchers only used a constructivist approach to criticize repressive policies that were deemed inappropriate. They prefer to fight terrorism with a soft power approach to reconstruct the perceptions of actors from both the state, society and terrorists themselves regarding the idea of terrorism. The researchers have not been able to explain the relationship between repressive policies taken by most countries (including Indonesia) with the social construction experienced by the country itself.

A somewhat different thought is shown by Martha Crenshaw in her writing. She uses the constructivism paradigm to explain the US security policy in counter-terrorism which is not solely influenced by national security interests. But she saw that the dominant influence actu- 


\section{Available Online at https://journal.unismuh.ac.id/index.php/otoritas}

Otoritas : Jurnal Ilmu Pemerintahan, 9 (2), October 2019, 110

Terrorism events that occurred before the events of $9 / 11$ :

PKI Madiun Rebellion (1948), DII / TII Rebellion

in West Java (1949), (APRA) 1950, South Maluku Republic (1950), DI / TII Rebellion in South

Sulawesi (1952), DI / TII Aceh Rebellion ( 1953), Free Papua Organization (1960s), PRRI /

PERMESTA (1958), PKI Rebellion (1965), East

Timor Fretilin rebellion (1975), Free Aceh

\section{Movement, 1977}

- Interpreted as a rebellion and criminal act (not terrorism)
Terrorism events that occurred after the events of

\section{9/11:}

The attack on the Jema'ah Islamiah group since 2001, Attack of the Indonesian Tauhid wal Jihad Group (ISIS Indonesia), since 2003
- Interpreted as a criminal act of terrorism

Figure 1. The Government of Indonesia in Percepting Terrorist Groups

Before and After the 9/11 Events

Source: Processed by the authors (2019)

\section{Terror Attack in Indonesia (2002-2016)}

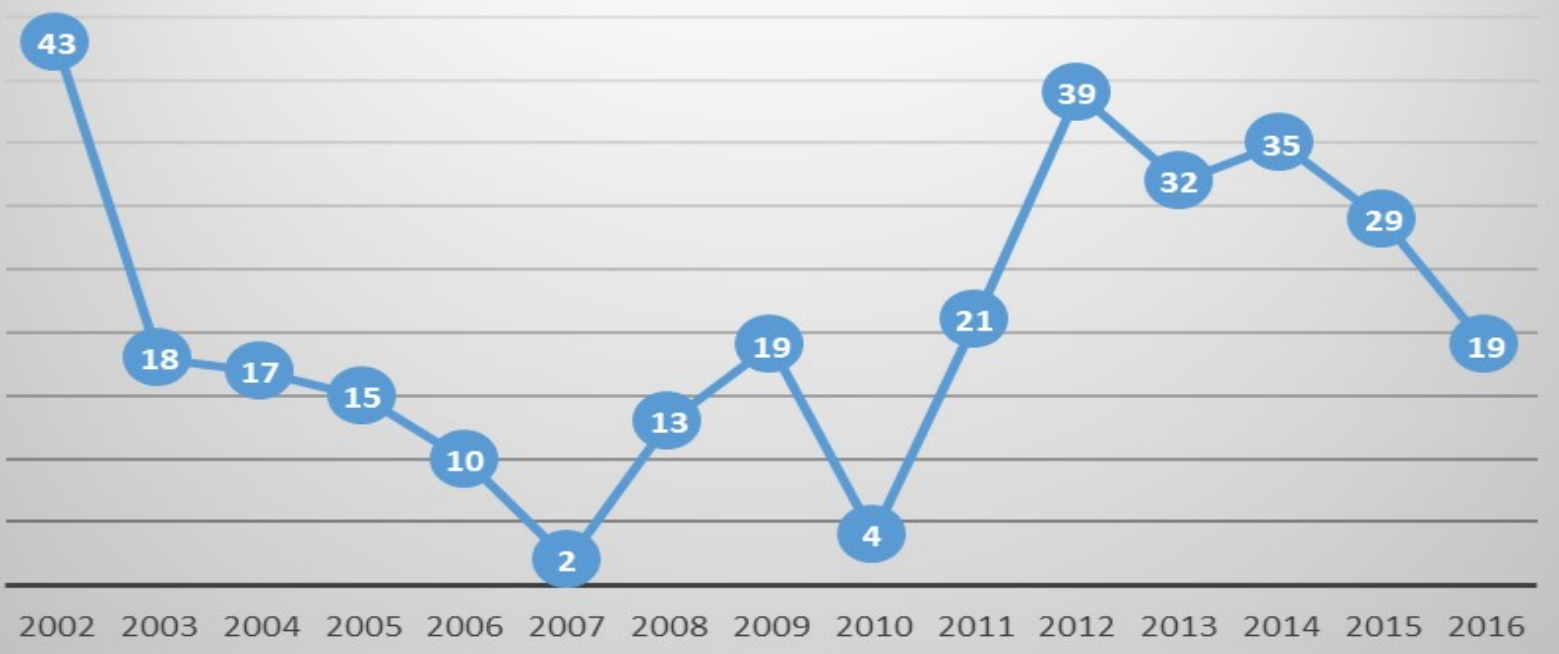

Figure 2. Terror attacks per year in Indonesia since 2002 to 2016

Source: Processed by the authors (2019) 
ally came from the process of domestic political dialectics. Which then builds the US government's perception of a "terrorist network" which then guides them to repressive policies (Crenshaw, 2010).

The author, in this case, will also use the constructivism paradigm to explain the factors that influence the policy of the Indonesian government in the context of counter-terrorism, but the author will look more broadly. Where if Martha Crenshaw only sees in terms of domestic political influence, the writer will look at the entire dialectical process of social construction that shapes identity and also the perception of the Indonesian government in seeing the threat of terrorism, especially the influence of international norms that believe that terrorism must be fought by the international community because it was considered a crime against humanity, which then influenced the Indonesian government to make repressive policies. This approach will show that the steps taken by the Indonesian government using a repressive approach to counter-terrorism are actually not rational actions (as in the tradition of realism or neo-realism), but these actions are influenced by social construction, in this case, international values and norms. So that at the same time the writer will also criticize the repressive policies taken by the Indonesian government in counter-terrorism which should use the reconstruction strategy of ideas to counter the emergence of terrorist movements. So that this research can provide updates in the scientific field related to the study of national security policies in the framework of constructivism thinking, in this case using the case of the Indonesian government's national security policy in counterterrorism.

This study will look at the social construction process that shapes identity and also the perception of the Indonesian government in seeing the threat of terror- ism, which guides the Indonesian government to repressive policies. In addition, it will also explain the effect of the idea of international norms (war on terror) to Indonesian policy. This approach will show that the steps taken by the Indonesian government using a repressive approach to counter-terrorism are actually actions influenced by the immaterial dimension, such as ideas and social construction (international norm structure).

\section{RESEARCH METHODS}

This study aims to determine what factors that influencing the Indonesian government to make repressive counterterrorism policies, since 2001. This is a qualitative research, and use the case study approach. Meanwhile, in an effort to build objectivity in this research, the data were collected through several stages. First, literature study on academic texts, official documents, and journalistic sources, both printed and online. In addition, the data were also obtained from various journals and books. Second, the data were collected by interviewing several competent parties, such as: Deputy of National Counter-Terrorism Agency, a member of parliament, and a former head of the Strategic Intelligence Agency.

\section{RESULTS AND DISCUSSION}

"War on Terror", which has become an international norm, has given effect to the Indonesian government in viewing terrorism. The Indonesian government is affected by international antiterrorism norms due to persuasions from the international community to participate in the "War on Terror" agenda. The first persuasion came from the United States, which was responded by President Megawati by visiting the United States with the main agenda to show support from Indonesia. During the visit, several agreement points were agreed upon, including aiding Indonesia to eradicate ter- 
rorism through several programs sponsored directly by the United States. One of the programs that became the United States' offer for Indonesia was the Antiterrorism Assistance (ATA) program (Kedang, 2017).

The ATA program is a program from the United States to aid the capacity building for counter-terrorism measures. Indonesia has become one of the prioritized countries to receive the aid of the ATA program from the United States. From 2003 to 2007, the total grant received by Indonesia from the United States through the ATA program was \$ 32.9M. In addition, in 2003, the United States also granted $\$ 3.5 \mathrm{M}$ of aid to the Indonesian government to build training facilities to increase the capacity against terrorism (Wise, 2005).

The United States also give aid in the form of training to the Indonesian military to deal with terrorism through the Combating Terrorism Fellowship Program (CTFP). This program was formed by the United States in 2002 to provide training and development partnerships with the military of partner countries of the United States. The United States in this case has provided a budget for training for mid-level officers to senior officers by the military of partner countries of the United States. The main objective of this program is to build the capacity of partner countries in facing terrorism threats at national, regional, or global levels. For the CPFT program, from 2003 to 2015, the United States has spent \$330,280,000 (United States Department of Defense, 2015). The funds spent by the United States prove the persuasion efforts for partner countries, including Indonesia, to participate actively in the fight against terrorism.

After it was agreed that Indonesia fully supports the United States-led global agenda related to the War on Terror, the Indonesian government began to formulate policies to counter-terrorism. The In- donesian government responded more to counter-terrorism measures after the Bali bombing incident on October 12,2002 , by issuing the Presidential Instruction No. 4 (2002) to address terrorism. The president gave a mandate to Susilo Bambang Yudhoyono (Minister for Politic and Security Affairs) to develop national policies and strategies for handling terrorism (Wise, 2005). Susilo Bambang Yudhoyono formed the DKPT (Coordination Agency for the Eradication of Terrorism), then in 2010, the institute was transformed to be the National Agency for CounterTerrorism (BNPT) (National Counter Terrorism Agency, n.d.). In 2004, the Indonesian government also formed an antiterror force (Detachment 88). This force was formed and funded by the US through the ATA program since 2003 (Wise, 2005).

Juridically, Indonesia issued an anti-terrorism law, namely Government Regulation Number 1 of 2002, which was changed to Law Number 15 of 2003 concerning the Eradication of Crime of Terrorism, and then changed to Law Number 5 of 2018, by including several points include the involvement of the Indonesian Army in eradication of terrorism, and changes the definition of the concept of terrorism, which include the phrase political and ideological motives in acts of terrorism.

The economic crisis that was happening since 1997 has made Indonesia urgently need economic assistance. With Indonesia joining the War on Terror, Indonesia received a lot of aids from the United States, for example: additional assistance and support through democratic reforms, post-tsunami reconstruction, education, and health. President Bush announced a provision of education to Indonesia in a period of 6 years with a total of \$157M (Kedang, 2017).

Besides that, the Indonesian government is also influenced by Australia. Australia initially had an interest in inves- 
tigating the Bali bombing in Indonesia. The interest of Australia felt rational because there were 88 Australian citizens to be the victims of the Bali bombings (Tempo.co, 2003). With this interest, Australia offered assistance to Indonesia in completing the Bali bombing case. Considering that at that time Indonesian-owned resources were felt to be inadequate, so it was feared that the handling of these cases would be hampered. Then there was a first-round of cooperation between Australia and Indonesia, in this case the formation of joint team to solve the Bali bombing case, which was ratified through a Memorandum of Understanding between the Indonesia and Australia on Countering Transnational Crime and Work Development, which periodically takes place every three years if the cooperation is to be continued (Ansari, 2016).

In addition, Australia and Indonesia also developed cooperation by establishing the Jakarta Center for Law Enforcement Cooperation (JCLEC). This institution aims to provide forums for the exchange of information and training for the development of capabilities in institutions, organizational infrastructure, human resources, and equipment, especially for the purposes of counter-terrorism (Ansari, 2016).

From the cooperation developed by Australia with Indonesia, it is materially beneficial for Indonesia because in this collaboration Indonesia benefited from the transfer of technology carried out to support the latest weapons support and supporting equipment operations. Detachment 88 has also received special equipment for counter-terrorism (Ansari, 2016). Even at the beginning of this collaboration was formed in the era of Megawati, the Government of Indonesia has received tens of millions of dollars in assistance from the Australian government (BBC, 2015). And to date, the JCLEC institution in the 2016 financial statements has recorded assets of IDR
10.150,399,688. Besides that, JCLEC throughout 2016 has received assistance from various sources of IDR $20,080,809,925$. And from the total funds, the largest funds came from the British and Australian governments. The UK has provided funds of IDR 5,620,837,125. While Australia provided assistance of IDR 4,441,024,711. And as an important note, the recorded cash funds owned by JCLEC in 2016 were IDR 10.150,399,688, and all of them are deposited in an account with ANZ bank which is actually one of the largest banks in Australia (Adi, 2016).

Assistance from the US and Australia has affected Indonesia to participate in the global agenda "war on terror". A large amount of funds that have entered Indonesia through various forms of counter-terrorism cooperation is enough to rationalize the Indonesian government's policy choices to participate in "war on terror".

The influence of other countries (Australia) on counter-terrorism policies in Indonesia, both in the form of persuasion and pressure, can be seen in the case of the plan to release the convicted terrorist case, Abu Bakar Baasyir. On Friday, January 18, 2019, Yusril Ihza Mahendra (President Jokowi's personal legal advisor), has publicly stated that the Indonesian president approved the release of Abu Bakar Baasyir, a convicted terrorist who was sentenced to 15 years in prison. Abu Bakar Baasyir has served his sentence for 9 years. And according to him, it can be given freedom on humanitarian grounds. Given the age of $\mathrm{Abu}$ Bakar Baasyir is 81 years old. And according to Yusril Ihza Mahendra when he said that Jokowi had approved the release of $\mathrm{Abu}$ Bakar Baasyir and his administration would be completed no later than 1 week from the issuance of Yusril's statement (Fauzy, 2018).

But then the plan to release the convicted terrorism case received pro- 
tests from various countries, especially Australia. Australian Prime Minister Scott Morrison expressed his protest to the Indonesian government and asked $\mathrm{Abu} \mathrm{Ba}-$ kar Baasyir not to be released. Even Yusril Ihza Mahendra revealed that there was some pressure in the form of protests over the plan to release $\mathrm{Abu}$ Bakar Baasyir from US and United Kingdom which tended to blame the policy plan (KompasTV, 2019).

After protests from several countries, especially Australia, the Indonesian government decided to cancel the freedom of Abu Bakar Baasyir. Even the international media, The Guardian, has released a news article stating that the Indonesian government immediately reviewed the plan to release Abu Bakar Baasyir's policy a few hours after getting a protest from Australian Prime Minister Scott Morrison. In the article entitled "Bali bombings: Indonesian reviews of $\mathrm{Abu} \mathrm{Ba}$ kar Bashir's release after Morrison's request" it was explained that the Australian government had communicated directly with the Indonesian government, and PM Scott Morrison requested that the Indonesian government give respect to Australia regarding the demands of Australians, especially families. Victims of the Bali bombings, so that Abu Bakar Baasyir was not released. And the demand was immediately responded by the Indonesian government a few hours later (after the protest was delivered by Scott Morrison), by announcing that the release of Abu Bakar Baasyir would be reviewed, until finally it was decided to be canceled (TheGuardian.com, 2019).

This dramatic policy change shows that the Indonesian government, in the context of policies related to terrorism, has gained quite a strong influence from several countries that have interests related to the issue of terrorism. The pressure is mainly from the United States, Britain, and Australia. The counterterrorism aid received by Indonesia from the US and Australia leaves the position of the Indonesian government with fewer choices regarding counter-terrorism policies. Indonesia's counter-terrorism policies need to be adjusted with the demands of the counter-terrorism donor countries.

The counter-terrorism policy made by the Indonesian government after 2001 was also influenced by the International Norms (International Low Instrument). After the 9/11 attacks, President Bush stated that "war on terror" as a struggle for the value of freedom and humanity. In addition, the perceptions regarding who is 'good' and who is 'bad' was also developed to legitimize the "War on Terror" agenda, as Bush said:

"Our enemy is a radical network of terrorists, and every government that supports them... ...This is the fight of all who believe in progress and pluralism, tolerance and freedom. We ask every nation to join us. We will ask, and we will need, the help of police forces, intelligence services, and banking systems around the world" (Bush, 2001).

The United States has determined that every terrorist groups are their opponents. Likewise, countries that support the groups that have been determined as terrorist groups have also been considered as opponents by the United States. Then the United States began to build a "war on terror" agenda.

Then the implementation of the "war on terror" agenda carried out by the United States is detrimental to the Muslim community in general. The 9/11 incident was carried out by Al-Qaeda groups who used Islamic identity. This phenomenon then makes the United States use a double standard in carrying out the "war on terror" agenda, and tends to harm the Muslim community in general. Though the Islamic world community in general (including Indonesia) also rejects the 
Available Online at https://journal.unismuh.ac.id/index.php/otoritas

Otoritas : Jurnal Ilmu Pemerintahan, 9 (2), October 2019, 115

methods carried out by Al-Qaeda groups and other radical groups that use Islamic identity in carrying out acts of terror (Fanani, 2011).

To succeed the "war on terror" agenda, United States has shared ideas to the international community to be used as norms in the form of international conventions or agreements that become international legal instruments under the United Nations.

There are two International Con- ventions on terrorism which are then used as the legal basis for the counterterrorism system in various countries. The two conventions were adopted by the United Nations before 2001. But the majority of UN member states ratified the two conventions after 2001. These two international conventions received rapid responses from countries in the world. First, The International Convention for the Suppression of Terrorist Bombings. This Convention adopted by the UN on

Table 1. Resolution Regarding Terrorism Issues by UN Security Council Since 2001-2017 Source: Processed by the authors (2019)

\begin{tabular}{|c|c|c|c|}
\hline \multicolumn{4}{|c|}{ UN Security Council Resolution Regarding Terrorism Issues } \\
\hline No & $\begin{array}{c}\text { Resolution Number and the Year Was } \\
\text { Decided }\end{array}$ & No & $\begin{array}{c}\text { Resolution Number and the Year Was } \\
\text { Decided }\end{array}$ \\
\hline 1. & Resolution 1368 (2001) & 24. & Resolution 1988 (2011) \\
\hline 2. & Resolution 1373 (2001) & 25. & Resolution 1989 (2011) \\
\hline 3. & Resolution 1377 (2001) & 26. & Resolution 2082 (2012) \\
\hline 4. & Resolution 1438 (2002) & 27. & Resolution 2083 (2012) \\
\hline 5. & Resolution 1440 (2002) & 28. & Resolution 2129 (2013) \\
\hline 6. & Resolution 1450 (2002) & 29. & Resolution 2133 (2014) \\
\hline 7. & Resolution 1452 (2002) & 30. & Resolution 2160 (2014) \\
\hline 8. & Resolution 1455 (2003) & 31. & Resolution 2161 (2014) \\
\hline 9. & Resolution 1456 (2003) & 32. & Resolution 2170 (2014) \\
\hline 10. & Resolution 1465 (2003) & 33. & Resolution 2178 (2014) \\
\hline 11. & Resolution 1516 (2003) & 34. & Resolution 2199 (2015) \\
\hline 12. & Resolution 1526 (2004) & 35. & Resolution 2249 (2015) \\
\hline 13. & Resolution 1530 (2004) & 36. & Resolution 2253 (2015) \\
\hline 14. & Resolution 1535 (2004) & 37. & Resolution 2255 (2015) \\
\hline 15. & Resolution 1566 (2004) & 38. & Resolution 2309 (2016) \\
\hline 16. & Resolution 1611 (2005) & 39. & Resolution 2322 (2016) \\
\hline 17. & Resolution 1618 (2005) & 40. & Resolution 2341 (2017) \\
\hline 18. & Resolution 1735 (2006) & 41. & Resolution 2354 (2017) \\
\hline 19. & Resolution 1787 (2007) & 42. & Resolution 2368 (2017) \\
\hline 20. & Resolution 1805 (2008) & 43. & Resolution 2370 (2017) \\
\hline 21. & Resolution 1822 (2008) & 44. & Resolution 2395 (2017) \\
\hline 22. & Resolution 1904 (2009) & 45. & Resolution 2396 (2017) \\
\hline 23. & Resolution 1963 (2010) & & \\
\hline
\end{tabular}


December 15, 1997, and ratified by 164 United Nations member states. Second, the Convention for the Suppression of the Financing of Terrorism. This Convention adopted by the General Assembly of the UN on December 9, 1999, and ratified by 173 countries. The conventions received an extraordinary response from United Nations member states. These conventions were the most numerous and the fastest to be ratified by United Nations member states after the September 11, 2001 attacks (Thontowi, 2013). This shows the significant influence of the attacks in relation to the dynamics of the development of international terrorism issues, which impacted countries around the world, including Indonesia. And Indonesia ratified the two conventions in 2006.

Moreover, from 2001 until 2017 the UN Security Council has issued 45 resolutions using terrorist or terrorism keywords. Resolution from the UN Security Council which is very influential is Resolution 1373 (2001). This resolution was a response to the 9/11 attack (United $\mathrm{Na-}$ tions Security Council, n.d.). The list of resolutions of the UN Security Council related to the terrorism, which was made from 2001 to 2017 , can be seen in the following table 1.

Basically, the issue of terrorism has become an international norm. The evidence includes the 30 international instruments set as a reference in dealing with terrorism internationally - 16 of them are universal and 14 are regional (United Nations, 2008).

The United Nations as an international structural institution shows its seriousness in responding to terrorism. The United Nations General Assembly issuing a resolution $60 / 288$ on September 8, 2006. The resolution aimed at creating a strategy that can be implemented at national, regional, and global levels to fight terrorism. For the first time at the United Nations, all member states agreed to a mutually agreed resolution. The resolution put the emphasis for the international world to not only state rejection against terrorism, but also to individually and collectively do the same (United Nations Office of Counter-Terrorism, 2006).

The encouragement to each country to follow the international norms related to counter-terrorism stated in resolution 60/288, (in Plan of Action point 6) reads: "To consider becoming parties without delay to the United Nations Convention against Transnational Organized Crime and to the three protocols supplementing it, and implementing them" (United Nations, 2006). The above resolution indicates that the United Nations strongly encourages all countries to implement international instruments in their national-level counter-terrorism measures.

All international instruments, which have been made related to terrorism, have shown that tackling or fighting terrorism has become an international norm constituted by international law, which will be adopted by United Nations member states and implemented at the national level of each country.

Martha Finnemore and Kathryn Sikkink have explained the influence of international norms in policy developments and the behavior of the state, (Finnemore \& Sikkink, 1998). Indonesia as a part of the United Nations, automatically bound to the rules agreed upon by the United Nations. The Indonesian government's counter-terrorism policy must follow international law because ratified international conventions have legal consequences that must be followed by the Indonesian government (Muna, 2011). Indonesia has ratified 8 from 16 international conventions related to the counterterrorism issues, applied in national law (Ministry of Foreign Affairs of the Republic of Indonesia, 2016).

Universal anti-terrorism instruments that have been approved must be 
obeyed by the countries that have agreed. This was encouraged by the United Nations by issuing a guideline on how to implement the international conventions at the national level. In that guideline, in the third paragraph states that:

\begin{abstract}
"After ratifying the universal anti-terrorism instruments, it is imperative for States to proceed with their legislative incorporation. This is vital not only to ensure effective implementation of counter-terrorism measures but also to create a legal basis for use by practitioners. While the universal anti-terrorism instruments may serve as a useful legal basis for the criminalization of terrorist offenses" (United Nations, 2006).
\end{abstract}

The United Nations developed a guideline for the countries to make legislation or rules. It was also intended to serve as a common reference in making legislation for all the countries and to make it easier for the United Nations to evaluate the activities of the War on Terror carried out by each country (United Nations, 2006).

The compliance of the Indonesian government with international norms that have been stated in several international conventions or United Nations resolutions on counter-terrorism matters is evident in several instruments of counterterrorism rules in Indonesia. In the academic text of Amendment to Law No. 15 of 2003, it is shown that the policies developed by the Indonesian government have had a strong influence from the international norms. For example, it has been explained in the academic text that one of the considerations for the development of national legal instruments related to anti-terrorism is the international norms that consider terrorism as an ex- traordinary crime. This is also one of the reasons for the issuance of anti-terrorism regulations and their retroactive application to the Bali bombing case. The definition of extraordinary crime is a gross human rights violation that comprises of genocide and crime against humanity (in accordance with the Rome Statute). Terrorism is considered an extraordinary crime due to its difficulty to disclose because it is a trans-boundary crime and it involves an international network (Republic of Indonesia National Law Development Agency 2011, 6).

The academic text of Amendment to Law No. 15 of 2003 also explains that one of the considerations was the plan to amend the Law, because the United Nations encouraged that every act linked to terrorism, such as funding, planning, preparation, and implementation of terrorist acts or support for terrorists must be punished. In addition, the United Nations wants terrorism to be categorized as a serious criminal offense. This shows that the counter-terrorism policy in Indonesia is strongly influenced by international structures (Republic of Indonesia National Law Development Agency 2011, 56).

The process of combating terrorism in Indonesia does not solely consider the national security conditions, but it also considers the objective conditions at the international level. This can be proven by the narrative of consideration in the Law Number 15 of 2003 at points a, b, c, $\mathrm{d}$, and e which read:

whereas in realizing the national goals as intended in the Preamble of the 1945 Constitution, namely to protect the entire Indonesian nation and all Indonesian interests, to promote general welfare, to enlighten the nation's life and to take part in maintaining the world order based on freedom and eternal peace as well as social welfare, it is absolutely necessary to have consistent and continuous law enforcement. 
whereas the series of bombing incidents in the territory of the Republic of Indonesia has caused the loss of life with no regard to the victims, has caused widespread fear in society, and the loss of property, causing a broad impact on social, economic, political life and international relations.

whereas terrorism is a crossborder, organized crime with a broad network so that it is a threat to peace and national as well as international security.

whereas in order to restore an orderly and secure community life, and to establish a strong legal platform and legal certainty in overcoming urgent issues in the eradication of terrorism, with reference to international conventions and national laws and regulations related to terrorism, the President of the Republic of Indonesia has stipulated Government Regulation Number 1 of 2002 concerning the Eradication of Terrorism.

whereas based on the considerations mentioned hereinabove in items a, b, c, and d, it is necessary to stipulate Government Regulation Number 1 of 2002 concerning the Eradication of Terrorism.

Terrorism that is considered a threat by the international community has affected the Indonesian government to participate in the War on Terror, one of which is by making legal instruments to tackle terrorism. Even the establishment of anti-terrorism law instruments in Indonesia refers to the provisions in international conventions ratified by the Indonesian government as stated in the consideration narrative in point $d$, which states clearly that the establishment of an anti-terrorism legal basis in Indonesia refers to international conventions.

Another evidence of the influence of international norms is not only found in the narrative of consideration, but also in the general explanation of the Law Number 15 of 2003, especially in the fourth paragraph that reads:
"In order to create an orderly and secure climate, in view of international conventions and laws and regulations related to terrorism, and in order to create a strong legal platform and legal certainty in dealing with urgent issues in eradication of terrorism, the President of Indonesia has stipulated Government Regulation Number 1 of 2002 concerning the Eradication of Terrorism."

Here, it is once again shown that the universal international convention related to anti-terrorism becomes the basis or reference for the Indonesian government to make legal instruments at the national level to counter-terrorism.

When the Indonesian government expanded the notion of criminal acts of terrorism, it was also influenced by international norms. As explained in the academic text of Amendment to Law No. 15 of 2003, the expansion of criminalization was carried out. For example, those in Articles $6,7,8$, and 10 of the government regulations No. 1 of 2002, which is derived from Article 479a to Article 479r, Law No. 4 of 1976 and Law No. 2 of 1976 originated from the ratification of three International Conventions concerning flight crime and crimes against flight facilities, namely: 1). The Hague Convention, 1970 (Convention for the Suppression of Unlawful Seizure of Aircraft), 2). Tokyo Convention, 1963 (Other Acts on certain Actions on Board Aircraft) and 3). Montreal Convention, 1971 (Convention for the Suppression of Unlawful Acts against the Safety of Civil Aviation) (Republic of Indonesia National Law Development Agency 2011, 62). 
In addition, the Article 9 of Law No. 1 of 2002 describes the use of firearms in terrorist act, actually derived from Law No. 12/Drt/1951 concerning firearms, which later added a special element in the form of "dolus specialis" in the form of "with the intention to do terrorism act" relating to the Convention Against Terrorist Bombing (1977) (Republic of Indonesia National Law Development Agency 2011, 62).

The consideration of the expansion of criminalization in the acts of terrorism in Indonesia is the possibility of "actual harm" and the emergence of "potential harm". Considerations related to "potential harm" in this case are associated with "technological terrorism" that utilizes chemicals, biological weapons, radiology, microorganism, radioactive, and their components, which have been regulated in Article 12 of the Law No. 1 of 2002. In addition, there is a possibility of action to collect material or property that will be used to carry out terrorism act as stipulated in Article 11 of Law No. 1 of 2002 originated from the Convention on Physical Protection of Nuclear Materials (1976) (Republic of Indonesia National Law Development Agency 2011, 62).

The influence of international norms on the Indonesian government's policies regarding terrorism can also be seen in Indonesia's participation in the Counter-Terrorism Committee (CTC). This requires the Indonesian government to be active in various forms of cooperation with international institutions, especially in the context of prevention and eradication of terrorism. CTC was formed based on the UN Security Council Resolution No. 1373 of 2001. The consequence of the membership status for the Indonesian government is the obligation to compile and submit an annual written report to the committee regarding what has been achieved and what is being carried out to counter-terrorism (Wuryandari, 2014). This is intended to ensure that all the activities carried out by the Indonesian government are within the lines of the international norms. Even when the Indonesian government wants to make bilateral or regional cooperation in counter-terrorism, the nature of the collaboration must follow the international norms (Hamidin, 2018).

In this case, Indonesia must follow international norms. The country must show partiality towards the global agenda to fight in the War on Terror and avoid being perceived as supportive of terrorism. Indonesia must learn from the waning issue of the Cold War (1990s) when the United Nations identified Libya, Sudan, and Afghanistan as sponsors of terrorist groups and then the United Nations security council gave economic sanctions to the three countries (Messmer \& Yordan, 2010). If Indonesia does not want to get sanctions from the international world, Indonesia must comply with the existing norms by supporting and becoming part of the global agenda to fight in the War on Terror.

The repressive counter-terrorism policy made by the Indonesian government was also influenced by the history or experience of Indonesia in the face of terrorism threats. Ian Hurd explains that "new policy ideas are shaped by preexisting dominant ideas and their relationship to experienced events" (Hurd, 2008). In counterterrorism by the Indonesian government, since 2001 is strongly influenced by the identity that is built from the social construction that has formed the international norms and the influence of Indonesian history or experience in dealing the threat of terrorism.

For the Indonesian government, terrorism is also interpreted as a national threat. In the Indonesian Defense White Paper (2015 edition), it has been explained that the Indonesian government interprets terrorism as a real or physical threat to the national security and it be- 
comes a priority for the country (Defense Ministry of the Republic of Indonesia, 2015). The perception related to the threat of terrorism influenced by Indonesia's experience in dealing with terrorist threats, so that the Indonesian government responds with repressive policies because these threats are one of the country's priorities. Since the 2000s the Indonesian government has been faced with several terror attacks which have resulted in fatalities from civil society

One of the national goals set out in the 1945 Constitution is to protect the motherland and all its people (Defense Ministry of the Republic of Indonesia, 2015). When the author conducted an interview with the former head of the Strategic Intelligence Agency, Soleman B. Ponto, regarding the meaning of terrorism threats to Indonesia, he explained that terrorism is interpreted as a physical threat, especially a threat to the safety of Indonesian citizens who, in many cases, have been victims of terrorist acts (Ponto, 2018).

For the Indonesian government, the threat of terrorism is not only interpreted as a physical threat, but also interpreted as a threat to the national's ideology, called Pancasila (the five principles). As the foundation and ideology, Pancasila is fundamental in the order of life of the nation. As the basis of the nation, Pancasila is the source of all sources of law that apply in Indonesia. As a state ideology, Pancasila is the philosophy and worldview of the Indonesian people that contains moral values, ethics and noble ideals, and goals that will be achieved by the Indonesian people. The application of Pancasila values is believed to reduce the activities of radical groups in the community (Defense Ministry of the Republic of Indonesia, 2015).

In a scientific seminar, one of the state officials, the Minister of Home Affairs, Tjahjo Kumolo, said that radicalism and terrorism are the main threats to
Pancasila and Indonesia's diversity (Gloria, 2017).

In handling the national security issues, in Indonesian history, it has been noted that Indonesian security forces use more repressive approaches. For example the treatment of the Indonesian government in dealing with several rebellions in the past such as: PKI Madiun Rebellion in 1948, DII / TII Rebellion in West Java in 1949, Rebellion of the organization of the Republic of South Maluku in 1950, rebellion of the Free Papua Organization in the 1960s, Rebellion of the Indonesian Communist Party in 1965, rebellion of Timor Timur 1975, rebellion of the Free Aceh Movement in 1977, etc. Indonesian forces have used a repressive approach in dealing with these rebellions, and are considered to have violated the human rights norms by the international community. For example, Human rights violations committed by the Indonesian government in handling PKI cases in 1965. In this case, estimated between 500,000 up to $1,000,000$ people were killed, and more than 100,000 people were detained for the period between several days to more than 14 years without the justice (Amnesty International, 2015). The other example is in the case of the 1975-1999 Fretilin (Timor Lorosa'e) rebellion, Indonesian forces allegedly killed 100,000 Timor Lorosae's people. Even, since Indonesia invaded Timor Lorosa'e on 7 December 1975, the invasion was immediately condemned by the United Nations. On December 22, the UN Security Council unanimously passed resolution 384 which recognized the rights of Timor Lorosa'es people who were nonnegotiable for self-determination and independence (Kusuma, 2017).

Although Indonesia has undergone reform in 1999, including reforms in the military sector, but the repressive character possessed by Indonesian security forces has not been lost (Timur, 2015). Based on the historical experience of the 
Indonesian government, it has shaped Indonesia's perspective in dealing with the threats of national security, including terrorism. Indonesia has continued to implement a repressive approach in dealing terrorism which is considered a threat to Indonesia's national security, even though the Indonesian government has reformed in 1999, and is committed to respecting human rights. But in practice, the Indonesian government still does a lot of human rights violations in counterterrorism.

Indonesia's decision to join the "war on terror", and use the repressive approach to counter-terrorism also influenced by the existence of several terror attacks that have taken place in the country. This phenomenon can minimize the resistance of the House of Representatives (DPR) and the Indonesian people (Owens \& Pelizzo, 2013).

Several bomb attacks in Indonesia carried out by radical groups have raised a curse from the Islamic community in Indonesia in general. This adds indirect support for the government to implement repressive policies in the face of terrorism threats. It also reduces the issue of democracy and human rights that are used to reject the government's policies (Schneier, 2009).

\section{CONCLUSION}

The Indonesian government has made a counter-terrorism legal instrument starting in 2001. And by coincidence, the making of counter-terrorism policies in Indonesia was carried out after the 9/11 event. Even though the phenomenon of terrorism that occurred in Indonesia existed before 2001. Even since Indonesia became an independent country, there have been many events that can be classified into the phenomenon of terrorism. But the Indonesian government responded by making legal instruments after 2001. Making legal instruments, as well as making anti-terror special forces carried out by the Indonesian government since 2001 was caused by several factors: First, the persuasion from the international community, especially from the United States and Australia by offering aids to the Indonesian government through several programs, has made Indonesia join the fight against terrorism as a global agenda. Second, The influence of international legal norms. Indonesia has ratified several international conventions governing counter-terrorism. Therefore, Indonesia is obliged to follow the rules agreed upon in international conventions, especially those contained in the conventions that have been ratified by the Indonesian government. Third, the Indonesian government's perception in understanding the threat of terrorism. Terrorism is interpreted as a threat to Indonesia's national security, especially the threat to Indonesian citizens and towards the Pancasila.

The Indonesian government has created national legal instruments and created special anti-terror forces that have a repressive character. However, the repressive approach has not been able to reduce the number of terrorist attacks in Indonesia.

\section{ACKNOWLEDGEMENT}

We would like to thank Ministry of Research, Technology and Higher Education of the Republic of Indonesia; Universitas Muhammadiyah Yogyakarta; Universitas 17 Agustus 1945 Jakarta; Universitas Muhammadiyah Makassar who have supported this research.

\section{REFERENCES}
Adi, G. (2016). Financial Statements - Cash Basis and Independent Auditor's Report. jakarta. Retrieved from https://docs.wixstatic.com/ ugd/64963f_a0366a3b78b84c45b 3b44601d64b6347.pdf


Available Online at https://journal.unismuh.ac.id/index.php/otoritas

Otoritas : Jurnal Ilmu Pemerintahan, 9 (2), October 2019, 122

Almas, P. (2016, March). Kinerja Densus

88 Dinilai Bisa Gagalkan Upaya

Kontra Terorisme_Republika

Online. Republika.co.id. Retrieved

from http://

nasional.republika.co.id/berita/

nasional/hukum/16/03/29/

o4svuw361-kinerja-densus-88-

dinilai-bisa-gagalkan-upaya-

kontra-terorisme

Amnesty International. (2015). Indonesia:

Lima puluh tahun berlalu, para korban '65 masih menunggu kebenaran, keadilan, dan reparasi. jakarta. Retrieved from https:// www.amnesty.org/download/ Documents/ ASA2124962015INDONESIAN.pdf

Ansari, R. (2016). Kerja sama bilateral indonesia dan australia dalam penanganan terorisme di indonesia tahun $2002-2013$. Journal of International Relations, 2 (1), 88-96.

BBC. (2015, February 23). Soal antiterorisme, Australia perlu bantuan Indonesia. BBC.COM. Retrieved from https:// www.bbc.com/indonesia/ dunia/2015/02/150223_australia _abbott_terorisme

Benjamin, D. (2008). Strategic

Counterterrorism. Policy Paper, (7), 1-21.

Bush, G. W. (2001). Address to a Joint Session of Congress and the American People. Retrieved July 11, 2018, from https://20012009.state.gov/coalition/cr/ $\mathrm{rm} / 2001 / 5025$.htm

Crenshaw, M. (2010). Counterterrorism Policy and the Political Process. Studies in Conflict \& Terrorism,
(May 2015), 37-41. https://

doi.org/10.1080/1057610017504

34204

Defense Ministry of the Republic of Indonesia. (2015). Indonesian Defense White Paper (2015). jakarta: Kementerian Pertahanan Republik Indonesia. Retrieved from https://www.kemhan.go.id/ wp-content/uploads/2016/04/ BPPI-INDO-2015.pdf

Fajar. (2013, November 26). Ini 10 Tindakan Pelanggaran Densus 88 Menurut Komnas HAM - Kiblat. Kiblat.net. Retrieved from https:// www.kiblat.net/2013/11/26/ini10-tindakan-pelanggaran-hamdensus-88-menurut-komnas-ham/

Fanani, A. F. (2011). The global war on terror, American foreign policy, and its impact on Islam and Muslim societies. Indonesian Journal of Islam and Muslim Societies, 1(2), 205. https:// doi.org/10.18326/ijims.v1i2.205255

Fauzy, N. (2018, January 18). Abu Bakar Baasyir Akan Dibebaskan, Yusril: Tidak Betul Jokowi Melakukan Kriminalisasi Ulama.

Tribunnews.com. Retrieved from http://www.tribunnews.com/ nasional/2019/01/18/abu-bakarbaasyir-akan-dibebaskan-yusriltidak-betul-jokowi-melakukankriminalisasi-ulama?page $=2$

Finnemore, M., \& Sikkink, K. (1998). International Norm Dynamics and Political Change. International Organization, 52(4), 887-917.

Firmansyah, H. (2010). Upaya Penanggulangan Tindak Pidana Terorisme di Indonesia. Mimbar 
Available Online at http://journal.unismuh.ac.id/index.php/otoritas

Otoritas : Jurnal Ilmu Pemerintahan, 9 (2), October 2019, 123

Hukum, 23(2), 237-429. https:// doi.org/https:// doi.org/10.22146/jmh.16193

Gloria. (2017). Mendagri: Radikalisme dan Terorisme Ancaman Utama Pancasila. Retrieved August 18, 2018, from https:// www.ugm.ac.id/id/news/15095mendagri:.radikalisme.dan.teroris me.ancaman.utama.pancasila

Hamidi, A. Z. (2016). MALAYSIA'S POLICY ON COUNTER TERRORISM AND DERADICALISATION STRATEGY. Journal of Public Security and Safety, 6(2), 1-19.

Hamidin. (2018). Personal Interview to Deputy of International Cooperation for National Counterterrorism Agency. jakarta: BNPT.

Haryono, E. (2010). Kebijakan AntiTerorisme Indonesia: Dilema Demokrasi dan Represi. Jurnal Ilmu Sosial Dan Ilmu Politik, 14(2), 229-246.

Hülsse, R., \& Spencer, A. (2008). The Metaphor of Terror: Terrorism Studies and the Constructivist Turn. Security Dialogue, 39(6), 571 -592. https:// doi.org/10.1177/0967010608098 210

Hurd, I. (2008). Constructivism. In D. S. Christian Reus-Smit (Ed.), The Oxford Handbook of International Relations (pp. 298-316). Oxford: Oxford University Press.

Jamwal, N. S. (2003). Counter Terrorism Strategy. Strategic Analysis, 27(1), 1-29. Retrieved from https:// idsa.in/system/files/ strategicanalysis_jamwal_0303.pdf
Kedang, A. Y. (2017). Internasionalisasi dan Internalisasi Wacana War on Terror. Sospol, 3(2), 21-42.

Komisi III DPR RI. (2016). LAPORAN SINGKAT RAPAT DENGAR PENDAPAT UMUM KOMISI III DPR RI DENGAN KOMNAS HAM, PP MUHAMMADIYAH DAN KONTRAS. jakarta.

Komnas HAM. (2013). Pers Rilis terkait Tanah Runtuh. Retrieved August 3, 2018, from https:// www.komnasham.go.id/ index.php/siaranpers/2013/01/22/44/pers-rilisterkait-tanah-runtuh.html

KompasTV. (2019). PM Australia Protes Terkait Pembebasan Abu Bakar Ba'asyir. Indonesia: Kompas TV. Retrieved from https:// www.youtube.com/watch?v=z8r_FbHw78

Kusuma, A. J. (2017). Pengaruh Norma HAM Terhadap Proses Kemerdekaan Timor Leste dari Indonesia. Otoritas : Jurnal Ilmu Pemerintahan, 7(1), 1-13.

Kusuma, A. J. (2018). The Allegation of Human Rights Violation in the Process of Counter-Terrorism Acts in Indonesia by Densus 88 Force. Advanced Science Letters, 24(5), 3394-3398. https://doi.org/ https://doi.org/10.1166/ asl.2018.11384

Messmer, W. B., \& Yordan, C. (2010). THE ORIGINS OF UNITED NATIONS' GLOBAL COUNTER-TERRORISM SYSTEM. Historia Actual Online, 22 (September 2010), 173-182.

Ministry of Foreign Affairs of the Republic of Indonesia. (2016). Indonesia 
Available Online at http://journal.unismuh.ac.id/index.php/otoritas

Otoritas : Jurnal Ilmu Pemerintahan, 9 (2), October 2019, 124

dan Upaya Penanggulangan

Terorisme. Retrieved July 12,

2018, from https://

www.kemlu.go.id/id/kebijakan/

isu-khusus/Pages/

Penanggulangan-Terorisme.aspx

Muhammad, A. (2015). Indonesia's

Experience In The War on Terror.

Yogyakarta: The Phinisi Press.

Mukhtar, S. (2016). STRATEGI

PEMERINTAH INDONESIA

MENGHADAPI TERORISME

DALAM ERA DEMOKRATISASI.

Reformasi, 6(2), 143-153.

Muna, B. (2011). Hukum Internasional Pengertian Peranan dan Fungsi dalam Era Dinamika Global (2nd ed.). Bandung: P.T Alumni.

National Counter Terrorism Agency. (n.d.). Tentang BNPT. Retrieved from http://www.bnpt.go.id/ profil.php

Owens, J. E., \& Pelizzo, R. (2013).

Rethinking crises and the accretion of executive power: The "war on terror" and conditionality evidence from seven political systems. Asian Politics and Policy, 5(3), 321-336. https://doi.org/10.1111/ aspp. 12034

Ponto, S. B. (2018). Public Discussion and Personal Interview to Soleman $B$. Ponto (Head of Strategic Intelligence Agency). jakarta: Imparsial.

Republic of Indonesia National Law Development Agency. (2011). Academic Text Changing Law No. 15/2003. jakarta.

Ritchie, M. R. ; M. N. ; H. (2018). Terrorism - Our World in Data. Retrieved from https://ourworldindata.org/ terrorism

Sani, A. (2018). Public Discussion and Personal Interview to Asrul Sani (Member of Commission III, who was a member of the Special Committee on Amending the Terrorism Law). Jakarta.

Schneier, E. V. (2009). Reformasi and the Indonesian "War on Terror": State, Military and Legislative-Executive Relations in an Emerging Democracy. The Journal of Legislative Studies, 15(2), 219-239. https:// doi.org/10.4324/9780203849668

Sitorus, E. Y. (2016). THE PHILIPPINE NATIONAL SECURITY POLICY IN THE COUNTER TERRORISM. Jurnal Prodi Peperangan Asimetris, 3(2), 25-38.

Surwandono, S., Retnoningsih, T. A. S., Alkatiri, M. A. (2018). Prevention and Eradication of Terrorism Funding Criminal Act in Indonesia. Otoritas, 8(October), 130-142. https://doi.org/: https:// doi.org/10.26618/ojip.v8i2.1013

Tams, C. J. (2009). The Use of Force against Terrorists. The European Journal of International Law, 20(2), 359-397. https:// doi.org/10.1093/ejil/chp031

Tempo.co. (2003). Howard: Jumlah Korban Bom Bali Asal Australia 88 Orang. Tempo.co. Retrieved from https://dunia.tempo.co/ read/34364/howard-jumlahkorban-bom-bali-asal-australia-88 -orang

Tempo.co. (2013). VIDEO Kekerasan Densus 88 Beredar di Youtube. 
Available Online at http://journal.unismuh.ac.id/index.php/otoritas

Otoritas : Jurnal Ilmu Pemerintahan, 9 (2), October 2019, 125

Nasional.Tempo.co. Retrieved from https://nasional.tempo.co/ read/1206461/ada-ancaman-aksiteroris-polri-minta-masyarakattak-demo-22-mei

TheGuardian.com. (2019, January 21). Bali bombings: Indonesia reviews Abu Bakar Bashir's release after Morrison's request. TheGuardian.com. Retrieved from https://www.theguardian.com/ world/2019/jan/22/balibombings-indonesia-reviews-abubakar-bashirs-release-aftermorrisons-request

Thontowi, J. (2013). HAM di NegaraNegara Muslim dan Realitas Perang Melawan Teroris di Indonesia. Pandecta, 8(2), 127139.

Timur, F. B. (2015). Tentara Nasional Indonesia dan Hak Asasi Manusia. In M. M. A. (Ed.), Almanak Hak Asasi Manusia di Sektor Keamanan Indonesia - 2014 (1st ed., pp. 133159). jakarta: DCAF - Geneva Center for Democratic Control of the Armed Forces IDSPS - Institute for Defense Security and Peace Studies. Retrieved from https:// www.researchgate.net/ publication/296674503_Tentara_ Nasional_Indonesia_dan_Hak_Asasi _Manusia

United Nations. (2006). GUIDE FOR THE LEGISLATIVE INCORPORATION AND IMPLEMENTATION OF THE UNIVERSAL ANTI TERRORISM INSTRUMENTS. (United Nations, Ed.). New York: United Nations. Retrieved from https:// www.unodc.org/documents/ terrorism/Publications/ Guide_Legislative_Incorporation_I mplementation/English.pdf
United Nations. (2008). Status of international legal instruments related to the prevention and suppression of international terrorism. Retrieved July 12, 2018, from http://www.un.org/ga/ sixth/63/

Terrorism_Table_63rd.pdf

United Nations Office of Counter Terrorism. (2006). UN Global Counter-Terrorism Strategy. Retrieved July 20, 2018, from https://www.un.org/ counterterrorism/ctitf/un-globalcounter-terrorism-strategy

United Nations Security Council. (n.d.). Resolutions adopted by the United Nations Security Council since 1946. Retrieved July 17, 2018, from http://www.un.org/en/sc/ documents/resolutions/

United States Department of Defense. (2015). Regional Defense Combating Terrorism Fellowship Program. Washington DC. Retrieved from https:// open.defense.gov/portals/23/ Documents/foreignasst/ FY15_Regional_Defense_Combatin g_Terrorism_Fellowship_Program Report_to_Congress.pdf

Wise, W. M. (2005). Indonesia's War on Terror. Washington: United StatesIndonesia Society (USINDO). Retrieved from http://usindo.org/ wp-content/uploads/2010/08/ WarOnTerror.pdf

Wuryandari, G. (2014). Politik Luar Negeri Indonesia Dalam Menghadapi Isu Terorisme Internasional. Jurnal Penelitian Politik, 11(2). 